\title{
Public Service in the Environment Sector in Indonesia
}

\author{
Nawir Rahman ${ }^{a}$, Umi Farida ${ }^{b}$, Chuduriah Sahabuddin ${ }^{c}$, Mustakingd, \\ Yusriadi Yusriadie, ${ }^{a}$ Sekolah Tinggi Ilmu Keguruan dan Ilmu Pendidikan \\ Pembangunan Indonesia, Makassar, Indonesia, ' Sekolah Tinggi Ilmu Ekonomi \\ Amkop, Makassar, Indonesia, ${ }^{\mathrm{c}} \mathrm{Al}$ Asyariah University, Mandar, Indonesia,

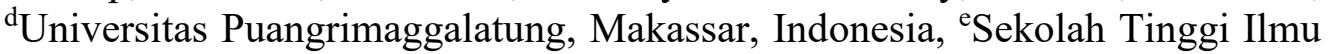 \\ Administrasi Puangrimaggalatung, Makassar, Indonesia,
}

The Online Based Environmental Information System Program (SIMAS-LH Online) aims to realise excellent service through the ease of the community to get environmental data and facilitate business actors in reporting the implementation of the environment in Indonesia. This study aims to analyse and explain the application of bureaucratic reform from aspects of public service and its implication in Indonesia. This research was carried out within the Makassar City Government of the South Sulawesi Province. The type of analysis used is a case study. The data sources in this study are primary data. Primary data is data obtained by researchers directly, while secondary information is data collected by researchers from existing sources. The determination of informants is determined sequentially. Informants in this study amounted to seven people, consisting of four service users and three service providers. Data collection techniques are carried out by document study, observation, and interviews. The results of the study show that the community can also participate in providing services with information technology. The district does not have to come directly to the Environmental Management Service to submit the file to the complaint. At present, the community participates in giving advice and claims that have been carried out. The application of information technology has also created efficient services to be able to take advantage of information technology and positively support infrastructure.

Keywords: Bureaucratic Reform, Public Service, Environment, Indonesia. 
International Journal of Innovation, Creativity and Change. www.ijicc.net

Volume 13, Issue 11, 2020

\section{Introduction}

Bureaucratic reform is a radical change aimed at improving the system of service and supervision and administering officials. This results in an increased public trust in the bureaucracy and to create a clean, professional, and responsible apparatus. Additionally, bureaucratic reform can provide excellent service while at the same time, implementing adequate supervision is highly dependent on legislation that forms the basis of the duties and authority of a bureaucracy. Furthermore, based on the desired system and procedure, an organisational structure is needed to determine the levels and types of positions, duties, and authorities as well as the number and qualifications of human resources required by considering the workload. One of the renewal efforts to support bureaucratic reform is to use information technology. This effort is considered sufficient to improve bureaucracy in Indonesia. Information technology can apply in state institutions such as legislative, executive, and judicial institutions. Constitution Number 32 of the Year 2009 on Environmental Protection and Management mandates that the government and local governments develop to support implementation and development environmental protection and management policies. The information system should be implemented in an integrated and coordinated way and must be published and accessible by the public (Umar, Amrin, et al., 2019).

An environment is a unit of space consisting of objects, power, conditions, and living systems with interrelated relations to shape the continuity of life and the welfare of humans and other living beings. Indonesia's forest area is 121 million ha or about 62 percent of Indonesia's land area and is a provider of production and environmental services. This potential becomes the capital in establishing a centre for economic growth in the region. In the context of world civilisation, there are two forest areas in Indonesia that are world heritage listed. These are the Lorenz National Park in Papua and Sumatra Heritage Tropical Rainforest (TRHS). The Environment Agency of South Sulawesi Province is responsible for the environment sector and seeks to encourage capacity building by taking concrete actions in realising the environmental quality and function improvements in the region. This is achieved through the provision of accurate and actual ecological data and information as material for consideration of policymaking. The Environmental Management Agency implemented an innovation in the form of "Online Based Information System of the Environment" (SIMAS-LH Online). This innovation allows the public to access online environmental information services in real-time (Hasbi et al., 2019). This innovation enables the Initiator or environmental manager to deliver their report efficiently (Yusriadi et al., 2019).

This program was launched since 2016 and was the first innovation in the field of environment in Indonesia. The program has four advantages. The first advantage is that this innovation makes it easier for people to obtain environmental data. Secondly, it makes it 
International Journal of Innovation, Creativity and Change. www.ijicc.net Volume 13, Issue 11, 2020

easier for business actors to report on the implementation of their environmental management. Thirdly, the data entered is directly processed automatically into information, such as information on river water quality and air quality. Based on the facts mentioned above, this phenomenon is unusual to develop. The public services in the environmental sector give a sign of innovation in the environmental field (Umar, Farida, et al., 2019). This phenomenon shows evidence that from various types of public services, the function of the green industry remains interesting to study.

\section{Method}

This research was carried out within the Makassar City Government of South Sulawesi Province based on being one of the most critical cities in economic development in Indonesia. The city continues to show very progressive growth from various sectors including its economic activities. The conditions of the Government system are a conducive, strategic position and also provide a variety of different economic growth and infrastructure support that continues to develop. The type of research used is a case study. The data sources in this study are directed to primary data which is data obtained by researchers directly. Secondary information is data collected by researchers from existing sources. Determination of informants was determined sequentially. Informants in this study amounted to 7 people, consisting of 4 service users and three service providers. Data collection techniques are carried out by document study, observation, and interviews. The data analysis technique used follows an interactive model which includes collecting, condensing data, presenting data, and verifying/drawing conclusions (Miles et al., 2014).

\section{Result and Discussion}

The application of information technology in South Sulawesi Province began in 2016. The technology used in the implementation of environmental services is through the Online Based Information System (SIMAS-LH Online) so that the public can access ecological information services online in real-time. SIMAS-LH Online is a web-based application used for environmental management. Starting from exploring environmental information, services (air quality, water quality, environmental permits), and waste. SIMAS-LH Online is an internet network system that uses an ISP type of special connection where the connection takes place. This connected to the internet 24 hours a day and seven days a week. On the website that is intended by the community, there is information about environmental permit services, garbage, complaints, and numbers that can be contacted by the public to be able to access data at SIMAS-LH Online in South Sulawesi Province. Infrastructure facilities in the utilisation of information technology in the process of managing the environment of South Sulawesi Province are excellent. This is revealed by SY informants as follows: 
International Journal of Innovation, Creativity and Change. www.ijicc.net Volume 13, Issue 11, 2020

"Infrastructure facilities at the office have equipped, computers, printers, internet networks, telephones can be used to support the service process in the office, in providing services, there are adequate infrastructure facilities. Modern service supporting technology makes services better (Interview, November 5, 2018)".

From the results of the interview, there was a change in service carried out by the Office of Environment of South Sulawesi Province. This, of course, can improve environmental services, with adequate support such as facilities and infrastructure, causing the adaptable organisational culture to accept new things that have a positive impact on public services. SIMAS-LH Online was integrated into South Sulawesi Province to take care of the environment and aims to make the service process transparent. Services are expected to be more open, and the public can know all information quickly and precisely. The service flow can be seen through SIMAS-LH Online, including when the community considers the type of permit and the initiator of the business being carried out. Reinforced by the results of interviews with $\mathrm{AB}$ (informant) as follows:

"SIMAS-LH online is very useful, information becomes accurate, and people have obtained information through available websites,. This provides transparency to service users and at the same time makes it easier to manage environmental permits, because the conditions are clear (Interview, November 4, 2018)".

The environmental permit service system also fully uses information technology by registering for the Regency/Company admin by entering the identity and scan results assigned by the Regency/Company on the website https://silhdsulsel.com/registrasi. In organising complaints, a service for the environments entirely uses information technology. The communities register merely using the identity card number and list the email on the website https://silhdsulsel.com and convey the party to the complaint, description of the claim, and upload evidence of the occurrence of irregularities. After that, SIMAS-LH online checks the charges made online. After the complaint data is entered into SIMAS-LH online, then later on the website https://silhdsulsel.com, the complaint go through to expenses processed, then they will see the date of the claim made. The description of the charge, the party, complaint, the status of the criticism has prepared or not, and the results of the service user's complaints process are coherent and complete. With the integration between SIMASLH online and this internal system, they are making environmental complaints services transparent. Transparency means the openness of the government in providing information related to the activities of managing public resources to those who need the information (Mardiasmo, 2004).

SIMAS-LH online currently functions as a data store when complaints come in and also data storage when the Decree has been made from the results of the claim. SIMAS-LH online can 
International Journal of Innovation, Creativity and Change. www.ijicc.net

Volume 13, Issue 11, 2020

process charges in more detail. The advantages contained in SIMAS-LH online make the complaints process run transparently. Reinforced by the results of interviews with GS informants as follows:

"I once submitted a complaint at SIMAS-LH online, related to environmental pollution, how to administer it by first registering and uploading evidence of environmental pollution that occurred. The registration process was quite easy because I only needed to enter the resident card number and email service users. After the complaint was received then I will be given a recommendation for a decision letter for the Regency/City environment office so that the proposals will follow up immediately" (Interview, November 2, 2018).

The community has widely conveyed complaints relevant today. Since 2016, when SIMASLH Online began, many people have already submitted complaints. Of the 21 claims entered from 2017 to 2018, all were responded to well by SIMAS-LH Online by providing recommendations to be followed up. The community does not need to come to the Environmental Management Office in Makassar City to ask about the requirements for an environmental permit or make a complaint. In communicating with the community to receive complaints from the public, currently communicating through SIMAS-LH Online is said to be effective. Community participation has begun to appear on SIMAS-LH Online. Participation using information technology can be supposed to work well. In the organisation of complaints services, the public can use SIMAS-LH online to collect evidence of environmental irregularities. They are seeing that the progress of the complaints submitted is still being used by the community well.

Indeed, a form of community participation is protecting the environment carried out by the Environmental Management Agency of South Sulawesi Province. Active community involvement in the whole process of activities can be seen as a medium for growing cohesiveness among communities, the community, and the government and also to foster the growth of a sense of belonging and responsibility for the programs carried out (Handayani, 2006).

The work process of SIMAS-LH online in providing environmental services can shorten and the level of bureaucracy can reduce. The online system requires a short amount of time to look at ecological permit services and complaints that come in. This means that the South Sulawesi Provincial Environmental Management Service has been responsible for always improving services to be more efficient with the SIMAS-LH Online. The search for complaints is only done by opening a website and seeing the results of the claim. A recommendation letter will appear and this makes it easy to take, just by downloading the recommendation. This is revealed by BK informants as follows: 
International Journal of Innovation, Creativity and Change. www.ijicc.net Volume 13, Issue 11, 2020

"The service is now excellent, I make a complaint, just open the website provided, after the results of the criticism that I made, given a recommendation decree to be followed up by the environmental management department, recommendations are enough to download, so I bother to come to the ecological service management of the southern Sulawesi province"(interview, November 3, 2018).

The use of information technology is expected to make the process of managing the environment faster and can facilitate the work of licensing environmental management officers. The method of controlling the environment by utilising information technology aims to reduce employee work processes. Information technology can be used and can make work from employees lighter. SIMAS-LH Online has helped the work of employees, especially when complaints will take a recommendation letter. The existence of standard operating procedures on SIMAS-LH Online also cause work methods to be implemented. RD informants explain this as follows:

"The standard operating procedure in utilising SIMAS-LH online already exists, both in environmental permit services and incoming complaints. So that the ecological management department can provide excellent service to the community (Interview, November 7, 2018)".

The implementation of SIMAS-LH Online back-office combined with an internal system for services makes the management of staff at the Office of Environmental Management of South Sulawesi Province efficient enough to input data once. By utilising information technology through one system, it can ease the burden on employees when compared with manual methods. Information technology aims to reduce the level of bureaucracy so that services become faster and more efficient. The community does not need to go through a vast bureaucracy but can be substituted with information technology, not even having to come to government agencies to access services. Today's environmental services still do not depend on face-to-face services. Information technology can utilise it properly. This is revealed by US informants as follows:

"The community already believes that by conducting online management, it will be quickly be processed by employees, so that they do not need to come directly to the office to arrange permits or environmental complaints" (Interview, November 5, 2018).

The same thing was expressed by EM informants as follows:

"The service process by the Environmental Management Service is now good, it is onlinebased, and the service is efficient and does not require a long time, even though our domicile is far away, it can still do management related to environmental permits" (Interview, November 7, 2018). 
International Journal of Innovation, Creativity and Change. www.ijicc.net

Volume 13, Issue 11, 2020

The proper functioning of information technology is also supported by people who already know about the application of information technology at the Office of Environmental Management of South Sulawesi Province. The dissemination of SIMAS-LH Online conducted by the South Sulawesi provincial government to the community much helped the program run well.

\section{Discussion}

Transparency in the context of organising public services is open, comfortable, and accessible to all parties who need the service. They are provided for adequately and efficiently (Ratminto \& Winarsih, 2005). Environmental services are organised through information technology, namely, SIMAS-LH, have been able to provide transparent services to the community. The community can obtain the form of information about the environment through information technology, namely, the SIMAS-LH website that is supplied to the public.

The permit and complaint procedures have been clearly and correctly explained. SIMAS-LH is designed to be able to show the progress of the service going well (Rijal et al., 2019). They are directly connected so that people can monitor the progress of permits and complaints so that in tracking the permit process or environmental charges. People prefer to use information technology media through the website. Awareness of the maximum utilisation of technology and knowledge of the importance of intelligent lifestyle are things that need to be considered by every element of society living in urban areas (Yusriadi et al., 2018).

The functioning of SIMAS-LH as a transparent information technology is also due to the government's support of South Sulawesi Province to make Makassar City a Smart City. Therefore, the government applies an online system in the public service process. The community began to believe in using information technology by choosing to take care of permits or complaints online. This empowers all components of government bureaucracy (institutions, management, and human resources) to become a professional government apparatus (Yusriadi et al., 2019).With online-based services, services will be more relaxed and more transparent. Therefore SIMAS-LH can run as expected that the community can get useful information through information technology provided by the government of South Sulawesi Province.

SIMAS-LH was included in the top 40 public service innovations in 2017. Changes from the Environmental Management Agency (DPLH) were also selected as 20 innovations from 2014 to 2017 representing Indonesia in the 2018 Edge of Government Innovation Award innovation competition by the OECD OPTION in Paris (Izzati, 2017). 
International Journal of Innovation, Creativity and Change. www.ijicc.net Volume 13, Issue 11, 2020

To provide maximum service to the community, DPLH continues to improve service quality. One of these improvements is the provision of data and information in the environmental field. The department previously used a manual system that took a long time, yet with SIMAS-LH the service became fast. The transparency of ecological data is now on one server (Mustafa et al., 2019). The obligation to report business actors also no longer need to be in the form of books, quite directly in the way of filling in SIMAS-LH. Participation occurs in the form of community development, in development activities, and in utilising and enjoying the results of the event (Suryono, 2001).

The success of development, initiative, and creativity of community members is born out of awareness and responsibility as human beings who live in a community and are expected to grow as a participant. Participation can be seen from the role of the population in utilising information technology provided by SIMAS-LH of South Sulawesi Province. The information technology produced by DPLH for the community, namely SIMAS-LH, can be appropriately used by the community. The city is currently utilising the program to see licensing requirements and provide complaints to the DPLH of South Sulawesi Province. In the system, a form that can be filled out and can also be used to make complaints about environmental violations through the website. The advantage of SIMAS-LH is that the community has plenty of space to submit claims to the South Sulawesi Provincial Government indefinitely and for 24 hours the city can access SIMAS-LH.

Participatory services certainly cannot work with only one party. The community are the recipients of the assistance, but are also the service providers who participate (Yusriadi, 2018a). With the existence of complaints in SIMAS-LH, DPLH South Sulawesi Province can answer charges quickly and accurately. The individual admin who deals with SIMAS-LH issues in communicating to the public so that communication from government agencies including the DPLH of South Sulawesi Province. The community takes place in two directions and carries out quickly and precisely (Awaluddin et al., 2019).

Participation as a manifestation of the desire to develop democracy through a decentralisation process which sought, among others, the needs for bottom-up planning by involving the community in the planning and development process of its population (Tilaar, 2009). At present, all complaints are responded to well by SIMAS-LH so that every complaint process with the evidence uploaded immediately followed up correctly. Given recommendations as a follow-up in the area for environmental violations.

The use of information technology in the implementation of environmental services in the DPLH is expected to accelerate services and reduce the workload of the DPLH of South Sulawesi Province. SIMAS-LH is considered to have facilitated the work of the officers, 
International Journal of Innovation, Creativity and Change. www.ijicc.net Volume 13, Issue 11, 2020

making it easier for officers to request permission to make complaints easier. Environmental management previously carried out with manual services can be substituted with an online system. Work can be complete with a single system. For SIMAS-LH, this is done by only inputting data in the order can manage more quickly. The efficiency with information technology can reduce the level of bureaucracy that must be accessed by the public. The application of technology can replace the face-to-face meetings at DPLH in South Sulawesi Province. This is so that people do not need to come directly to the office to access services so that services will run faster. Efficiency is a benchmark and is used for various purposes and provides a comparison between input and output (Mubyarto \& Hamid, 1987).

Information technology can use for all stages of service. The community can complete the permit or complaint requirements by entering data. The efficient use of information technology services is also because DPLH has been running online-based services. The community believes in the existence of information technology and is familiar with the online system so that the implementation of information technology-based services supported by community participation. The collaboration of several parties in improving the online service process in South Sulawesi Province must continue to enhance in utilising information technology. This is so that the server process can run efficiently. The Indonesian government has launched a reform of the bureaucracy that aims to develop a clean, efficient, effective, and productive administration (Yusriadi, 2018b).

\section{Conclusion}

The quality of information technology-based services is going well when viewed in terms of transparency. Information technology can help people who will see the progress of licensing and complaints. Information provided through SIMAS-LH technology, namely online licenses, and accusations that can be accessed by the public, can be well served. Information disclosure can be obtained by the community because most of the population has been aware of online permits. This is relevant for the complaints that are carried out in the Environmental Management Agency of South Sulawesi Province. The participation that is expected to occur with the use of information technology has also happened. At present, licensing and complaints officers in the environmental management office can fully utilise SIMAS-LH. It is felt that the SIMAS-LH procedure is correct when applied. Communities can also participate in providing services with information technology. The district does not have to come directly to the Environmental Management Service to submit the file to the complaint. At present, the community participates in giving advice and criticisms that have been carried out. The application of information technology has also created efficient services to be able to take advantage of information technology while positively supporting infrastructure. 
International Journal of Innovation, Creativity and Change. www.ijicc.net

Volume 13, Issue 11, 2020

\section{REFERENCES}

Awaluddin, A. Siraj, M. L. and Yusriadi, (2019). The effectiveness of the implementation of independent community empowerment programs In Bone District. International Journal of Scientific \& Technology Research, 8(8), 352-354.

Handayani, S. (2006). Perlibatan masyarakat marginal dalam perencanaan dan penganggaran partisipasi. Kompip Solo.

Hasbi, Sukimi, M. F. Latief, M. I. and Yusriadi, Y. (2019). Compromise In traditional ceremonies: A case study of the rambu solo' ceremony In Toraja Regency. Humanities \& Social Sciences Reviews, 286-291. https://doi.org/https://doi.org/10.18510/hssr.2019.7651

Izzati, N. (2017). Simas LH sulsel masuk 40 top inovasi pelayanan publik kemenpan. Rakyatku.Com. http://news.rakyatku.com/read/62282/2017/08/23/simas-lh-sulselmasuk-40-top-inovasi-pelayanan-publik-kemenpan

Mardiasmo, (2004). Otonomi manajemen dan keuangan Daerah. Andi.

Miles, M. Huberman, A. . and Saldana, J. (2014). Qualitative data analysis, A Methods Sourcebook (3rd ed.). Sage Publications.

Mubyarto, and Hamid, E. S. (1987). Meningkatkan efisiensi nasional. BPFE Yogyakarta.

Mustafa, D. Farida, U. and Yusriadi, Y. (2019). The effectiveness of public services through e-government in makassar City. International Journal of Scientific \& Technology Research, 9(1), 214-250.

Ratminto, and Winarsih, A. S. (2005). Manajemen pelayanan: pengembangan model konseptual, penerapan citizen's charter, dan standar pelayanan minimal. Pustaka Pelajar.

Rijal, S. Haerani, Y. Mayasari, R. E. and Yusriadi, Y. (2019). The effectiveness of implementation of government regulation number 41 the year 2011 on the development of youth entrepreneurship and pioneering and the provision of youth facilities and infrastructures In Kolaka. International Journal of Scientific \& Technology Research, 8(10), 177-188. http://www.ijstr.org/research-paper-publishing.php?month=oct2019

Suryono, A. (2001). Teori dan Isi Pembangunan. Universitas Negeri Malang. UM Press.

Tilaar, H. A. R. (2009). Kekuasaan dan Pendidikan: Manajemen pendidikan nasional dalam pusaran kekuasaan. Rineka Cipta. 
International Journal of Innovation, Creativity and Change. www.ijicc.net Volume 13, Issue 11, 2020

Umar, A. Amrin, M. M. Farida, U. Yusriadi, T. H. Bahtiar, A. Yahya, M. Nurnaningsih, A. S. Gunawan, H. Darwis, S. C. Jamaluddin, M. E. Akbar, Z. Sakkir, G. M. (2019). Onestop service policy as a bureaucratic reform in Indonesia. Academy of Strategic Management Journal, 18(2), 1-12. https://www.abacademies.org/articles/onestopservice-policy-as-a-bureaucratic-reform-in-indonesia-8027.html

Umar, A. Farida, U. and Yusriadi, Y. (2019). Leadership role in improving responsibility of employee's work in scope of general bureau of government of Bulukumba Regency. International Journal of Scientific \& Technology Research, 8(10), 121-125.

Yusriadi, (2018a). Bureaucratic reform barriers: A Case study on the one stop-integrated service office in bone regency. Jurnal Kebijakan Dan Administrasi Publik, 22(2), 146154. https://doi.org/https://doi.org/10.22146/jkap.34536

Yusriadi. (2018b). Bureaucratic reform to the improvement of public services Challenges for Indonesia. Publikauma: Jurnal Administrasi Publik Universitas Medan Area, 6. http://ojs.uma.ac.id/index.php/publikauma/article/view/1494

Yusriadi, Sahid, A., Amirullah, I., Azis, A., \& Rachman, A. A. (2019). Bureaucratic Reform to the Human Resouces: A Case Study on the One-Stop Integrated Service. The Journal of Social Sciences Research. https://arpgweb.com/pdf-files/jssr5(1)61-66.pdf

Yusriadi, S. A. Amirullah, I. Azis, A. and Rachman, A. A. (2018). E-Government-based bureaucratic reform in public service. 2nd International Conference of Communication Science Research (ICCSR 2018), 68-70. https://www.atlantispress.com/proceedings/iccsr-18/25904573 